http://jmscr.igmpublication.org/home/ ISSN (e)-2347-176x ISSN (p) 2455-0450

crossref DOI: https://dx.doi.org/10.18535/jmscr/v8i4.90

\title{
Clinical profile of HIV infected patients in a tertiary health care centre in Northern India
}

\author{
Authors \\ Dr Rajiv Raina ${ }^{1}$, Dr Swati Mahajan ${ }^{2 *}$, Dr Mohit Bajaj ${ }^{3}$ \\ ${ }^{1}$ Professor, General Medicine, Indira Gandhi Medical College, Shimla, HP \\ ${ }^{2}$ Junior Resident, General Medicine, Indira Gandhi Medical College, Shimla, HP \\ ${ }^{3}$ Junior Resident, Pediatrics, Indira Gandhi Medical College, Shimla, HP \\ *Corresponding Author \\ Dr Swati Mahajan
}

Senior Resident, Department of Medicine, DRRPGMC Tanda at Kangra Pin 176001, India

\begin{abstract}
Introduction: The Human Immunodeficiency Virus (HIV) is a lentivirus (subgroup of retrovirus) that causes HIV infection and over time Acquired Immunodeficiency Syndrome (AIDS). HIV causes progressive impairment in body's immune system leading to increased susceptibility to fatal opportunistic infections known as acquired immune-deficiency syndrome (AIDS). The aim of our study was to study the clinical profile of HIV infected patients.

Materials: It was an observational study including 127 HIV positive patients in a tertiary health care centre. According to the WHO case definition, HIV in adults and children 18 months or older is diagnosed based on positive HIV antibody testing (rapid or laboratory-based enzyme immunoassay).This is confirmed by a second HIV antibody test (rapid or laboratory-based enzyme immunoassay) and/or; positive virological test for HIV or its components (HIV-RNA or HIV-DNA or ultrasensitive HIV p24 antigen) confirmed by a second virological test obtained from a separate determination.

Observations: In our study, out of the 127 HIV/AIDS patients, majority 54(42.52\%) belonged to 31-40 years of age group, 71(55.9\%) were males, married patients were 121 (95.28\%), less educated group had majority with maximum among the group educated till 12th standard (53.54\%), majority of male subjects were drivers by profession(39.44\%) and females were housewives(80.36\%).Majority 44(34.64\%) had CD4 count between 251-500.

Conclusion: The present study found that most of the HIV infected patients were from sexually active age group. The commonest mode of acquiring infection was heterosexual contact, emphasizing the need to strengthen our Information education and communication (IEC) strategies to contain HIV/AIDS.

Keyword: $H I V, A I D S$.
\end{abstract}

\section{Introduction}

HIV infection continues to be a major global health problem. It causes ill-health among millions of people each year and ranks as the first leading cause of death from an infectious disease worldwide.
According to $\mathrm{WHO}$, there were 36.7 million [34.3-39.8] people living with HIV at the end of 2016 with 1.8 million [1.9-2.2] people becoming newly infected with HIV in 2016 globally and about 5000 new infections per day. ${ }^{1}$ There were 160,000 children $<15$ years and about $40 \%$ of 
new infections were among persons under age 25 . In 2016, 1.0 million [980 000-1.6] people died from HIV-related causes globally.

UNAIDS/WHO estimates show that about 20.9 million people were receiving ART by mid-2017, up from 15.8 million in June 2015, 7.5 million in 2010 , and less than 1million in $2000{ }^{2}$

The global prevalence of people living with HIV has increased more than fourfold since 1990, reflecting the combined effects of continued high rates of new HIV infections and the lifeprolonging impact of antiretroviral therapy. ${ }^{3}$

Globally the number of AIDS related annual deaths have decreased by $43 \%$ since 2003 while in eastern and southern Africa, the regions that are most affected by HIV, there has been a $36 \%$ reduction in AIDS related deaths since 2010. ${ }^{1}$

India currently has an estimated 2.1 million people living with HIV (PLHIV), third highest globally after South Africa and Nigeria. HIV prevalence among adults (15-49 years) in the country has been declining steadily from $0.38 \%$ in 2001 to $0.26 \%$ in 2015 . Overall, the estimated new HIV infections annually have reduced by 66\% over 2000- 2015 and annual AIDS-related deaths have also decreased by $54 \%$ since $2007 .{ }^{4}$ In 2016, there were an estimated 80, 000 new HIV infections and 62, 000 AIDS related deaths in India. Out of them, about 50\% adults and 33\% children are on ART treatment ${ }^{5}$

The hallmark of HIV disease is a profound immunodeficiency resulting primarily from a progressive quantitative and qualitative deficiency of the subset of T lymphocytes i.e. helper T cells. ${ }^{3}$ When $\mathrm{CD}^{+} \mathrm{T}$ cell numbers decline below a critical level, cell-mediated immunity is lost, and the body becomes progressively more susceptible to opportunistic infections .A number of mechanisms responsible for cellular depletion and/or immune dysfunction of CD4+ T cells have been demonstrated in vitro; these include direct infection and destruction of these cells by HIV, as well as indirect effects such as immune clearance of infected cells, cell death associated with aberrant immune activation, and immune exhaustion due to aberrant cellular activation with resulting cellular dysfunction. Patients with CD4+ $\mathrm{T}$ cell levels below certain thresholds are at high risk of developing a variety of opportunistic diseases, particularly the infections and neoplasms that are AIDS-defining illnesses. Diseases related to cardiovascular system, liver, kidneys, cognitive functions, malignancies and metabolic bone disease appear to be more common among HIV infected patients.

According to WHO case definition ${ }^{6}$, HIV in adults and children 18 months or older is diagnosed based on positive HIV antibody testing (rapid or laboratory-based enzyme immunoassay). This is confirmed by a second HIV antibody test (rapid or laboratory-based enzyme immunoassay) and/or positive virological test for HIV or its components (HIV-RNA or HIV-DNA or ultrasensitive HIV p24 antigen) confirmed by a second virological test obtained from a separate determination.

\section{Materials and Methods}

Set up and Design

Study Type: Observational cross sectional study.

Study Duration: One year period ( $1^{\text {st }}$ July 2016 to $30^{\text {th }}$ June 2017).

Site: Department of Medicine at Indira Gandhi Medical College and Hospital Shimla.

Study Population: The study population included HIV positive patients attending the ART clinic /Medicine OPD/admitted in Medicine ward during the study period.

Sample Size: All patients fulfilling inclusion criteria during study period were enrolled.

\section{Inclusion Criteria}

1. All HIV positive patients admitted in Medicine ward or attending ART clinic /Medicine OPD and willing to participate in the study.

2. Age more than 18 years.

Exclusion Criteria: Patients not giving consent for inclusion in study. 
All the subjects were informed about the study protocol and written informed consent was obtained.

\section{Results}

\section{Demographic Profile of Enrolled Subjects}

Table 1: Age Wise Distribution of Subjects

(N-127)

\begin{tabular}{|l|c|c|}
\hline Age Group (In years & No. of Subjects & Percentage \% \\
\hline $18-30$ & 15 & 11.81 \\
\hline $31-40$ & 54 & 42.52 \\
\hline $41-50$ & 44 & 34.65 \\
\hline$>50$ & 14 & 11.02 \\
\hline
\end{tabular}

Table 2: Gender Wise Distribution of Subjects (N-127)

\begin{tabular}{|l|c|c|}
\hline Sex & No. & Percentage \\
\hline Male & 71 & $55.9 \%$ \\
\hline Female & 56 & $44.1 \%$ \\
\hline Total & 127 & $100.0 \%$ \\
\hline
\end{tabular}

Table 3: Distribution of the Subjects based on Marital Status (N-127)

\begin{tabular}{|l|c|c|}
\hline Marital Status & No. & Percentage \\
\hline Married & 121 & $95.28 \%$ \\
\hline Unmarried & 6 & $4.72 \%$ \\
\hline Total & 127 & $100.0 \%$ \\
\hline
\end{tabular}

Table 4: Distribution of the Subjects on the basis of Education (N-127)

\begin{tabular}{|l|c|c|}
\hline Education & No & Percentage \\
\hline Illiterate & 37 & $29.1 \%$ \\
\hline Upto $12^{\text {th }}$ Standard & 68 & 53.54 \\
\hline Graduate & 22 & $19.3 \%$ \\
\hline Post Graduate & 10 & $7.87 \%$ \\
\hline Total & 127 & $100.0 \%$ \\
\hline
\end{tabular}

Table 5: Distribution of the subjects on the basis of HIV Status of Spouse

\begin{tabular}{|l|c|c|}
\hline Hiv Status Of Spouse & No. & Percentage \\
\hline Positive & 90 & $74.38 \%$ \\
\hline Negative & 31 & $25.62 \%$ \\
\hline Total & 121 & $100.0 \%$ \\
\hline
\end{tabular}

Table 6: Profession Wise Distribution of Male

Subjects

\begin{tabular}{|l|c|c|}
\hline Profession & No. of Subjects & Percentage \\
\hline Driver & 28 & $39.44 \%$ \\
\hline Labourer & 9 & $12.68 \%$ \\
\hline Govt. Employee & 5 & $7.04 \%$ \\
\hline Factory Worker & 5 & $7.04 \%$ \\
\hline Farmer & 17 & $23.95 \%$ \\
\hline Shopkeeper & 7 & $9.85 \%$ \\
\hline
\end{tabular}

Table 7: Profession Wise Distribution of Female Subjects

\begin{tabular}{|l|c|c|}
\hline Profession & No. of Subjects & Percentage \\
\hline Housewife & 45 & $80.36 \%$ \\
\hline Labourer & 2 & $3.57 \%$ \\
\hline Farmer & 5 & $8.93 \%$ \\
\hline Shopkeeper & 2 & $3.57 \%$ \\
\hline Govt. Employee & 2 & $3.57 \%$ \\
\hline
\end{tabular}

Table 8: Mode of Transmission (History Wise) Among Subjects (N-127)

\begin{tabular}{|l|c|c|}
\hline Mode Of Transmission & No. of Subjects & Percentage \\
\hline Sexual & 112 & $88.19 \%$ \\
\hline I.V Drug Abuse & 11 & $8.66 \%$ \\
\hline Blood Transfusion & 4 & $3.15 \%$ \\
\hline
\end{tabular}

Table 9: Symptom Profile of Enrolled Subjects (N-127)

\begin{tabular}{|l|c|c|}
\hline Symptoms & No. of Subjects & Percentage \\
\hline Fever & 12 & 9.44 \\
\hline History Of Bony Pains & 25 & 19.68 \\
\hline Weight Loss & 8 & 6.29 \\
\hline History Of Fracture & 22 & 17.32 \\
\hline Fatigue & 40 & 31.49 \\
\hline
\end{tabular}

Table 10: Drug Regimen of HAART (N-127)

\begin{tabular}{|l|c|c|}
\hline Drug Regimen & No. of Subjects & Percentage \\
\hline ZLN & 49 & $38.58 \%$ \\
\hline TLE & 71 & $55.90 \%$ \\
\hline ZLE & 1 & $0.79 \%$ \\
\hline SLN & 2 & $1.57 \%$ \\
\hline ZL/atz/r & 1 & $0.79 \%$ \\
\hline ZL/lop/r & 1 & $0.79 \%$ \\
\hline TL/atz/r & 1 & $0.79 \%$ \\
\hline Pre ART & 1 & $0.79 \%$ \\
\hline
\end{tabular}

Table 11: Distribution of CD4 Count (N- 127)

\begin{tabular}{|l|c|c|}
\hline CD4 Count & No. of Patients & Percentage \\
\hline$<50$ & 14 & 11.02 \\
\hline $51-100$ & 16 & 12.5 \\
\hline $101-150$ & 18 & 14.1 \\
\hline $151-200$ & 11 & 8.6 \\
\hline $201-250$ & 10 & 7.8 \\
\hline $251-500$ & 44 & 34.64 \\
\hline$>501$ & 14 & 11.02 \\
\hline
\end{tabular}

\section{Discussion}

\section{Socio-demographic Profile}

In our study, out of the 127 subjects, majority 54 (42\%) were belonging to $31-40$ years of age, followed by 44 (34.65\%) belonging to $41-50$ years age group followed by15 (11.81\%) belonging to 18-30 years age group and 14(11.02\%) belonging 
to $>50$ years age group. (Table no. 1). Our findings are consistent with a study conducted by Umesh $\mathrm{S}$ Joge et $\mathrm{al}^{7}$ over $801 \mathrm{HIV} / \mathrm{AIDS}$ positive patients who found that majority $471(58.80 \%)$ were belonging to 30-39 years age group. Laxmi Gautam et al. $^{8}$ also found that out of 385 HIV/AIDS patients taken, majority 275 (71.43\%) belong to 30-45years age group. Kamath et al ${ }^{9}$ also reported $61.3 \%$ of patients in age group of 31-45 years in their study.

In our study mean age of HIV infected subjects was 40.3 years (32-48yrs) which is in concordance with studies by Carr et $\mathrm{al}^{10}$ and Alonge TO et $\mathrm{al}^{11}$ reporting mean age of $34 \pm 10.1$ years and $41.3 \pm 10$ years respectively. This is explained by more migration of young individuals for jobs leading to high chances of sexual promiscuity.

It was found that out of total 127 subjects, 71 $(55.9 \%)$ were males, and $56(44.1 \%)$ were females (Table no.2). Gender wise distribution showed male preponderance of HIV which is similar to the studies by Kamath et al. ${ }^{9}(75.3 \%)$, Sharma et $\mathrm{al}^{12}(81.3 \%)$ and Carr et $\mathrm{al}^{10}(74 \%)$.

It was observed that HIV/AIDS was more common in married patients $121(95.28 \%)$ as compared to unmarried patients $6(4.72 \%)$ (Table no.3). Abyramy Balasundaram et $\mathrm{al}^{13}$ also found that HIV/AIDS was more common in married patients $113(86.9 \%)$ as compared to unmarried patients $17(13.1 \%)$. In another study, M.A. Khan et $\mathrm{al}^{14}$ also found that HIV/AIDS was more common in married patients i.e. 218 (86.9\%)as compared to the unmarried patients.

It was observed that HIV/AIDS was more common in less educated group with majority among the group educated till 12th standard 68 $(53.54 \%)$ followed by the illiterate group 37 (29.1\%). HIV/AIDS was less common among the higher educated group (postgraduate) (7.87\%) (Table no. 4).This is in concordance with studies by Abyramy Balasundaram et $\mathrm{al}^{13}$ who observed that HIV/AIDS was more common in individuals with primary level of education $(46.9 \%)$ followed by individuals with secondary level of education
(37.7\%). Preeti Rai et. $\mathrm{Al}^{15}$ in their cross-sectional study observed that HIV/AIDS was more common among the illiterate patients group (26.92\%).

It was observed that out of the married 121 (95.28\%) subjects,90 (74.38\%) subjects had their spouse HIV/AIDS positive, 31 (25.62\%) subjects had their spouse HIV/AIDS negative (Table no.5). Umesh $\mathrm{S}$ Joge et $\mathrm{al}^{7}$ in their study found that out of married 769 (96\%) patients, 484 (62.94\%) patients had their spouse HIV/AIDS positive, 133 (17.29\%) patients had their spouse HIV/AIDS negative and $152(19.77 \%)$ patients had their spouse HIV/AIDS status unknown.

In our study, majority of male subjects $28(39.4 \%)$ were drivers by occupation followed by farmers $17(23.95 \%)$ (Table no. 6).In our study, 45(80.3\%) of females were housewives, $5(8.93 \%)$ were farmers, $2(3.57 \%)$ were labourers, shopkeepers and government employees (Table no. 7).

In our study, the mode of transmission was heterosexual in $88.17 \%$ (n-112) subjects. $8.6 \%$ (n11) subjects gave a history of intravenous drug use and $3.15 \%(n-4)$ of blood transfusion (Table no.8). The majority of patients gave a history of extramarital heterosexual contacts and history of visiting commercial FSW. In a study by Ghiya et al. ${ }^{16}$, the most common mode of transmission was heterosexual (65\%), followed by blood transfusion (13.8\%), vertical transmission $(9.8 \%)$ and unknown(10.6\%). In a study by Chakravarty $\mathbf{J}$ et $\mathrm{al}^{17}$, heterosexual contact was the commonest mode of transmission in $352(80.4 \%)$ patients followed by blood transfusion in $2.5 \%$.

\section{Clinical Profile}

In our study, generalised fatigue 40 (31.49\%) followed by bony pains $25(19.68 \%)$ and previous history of fracture $22(17.32 \%)$ were the commonest symptoms on presentation (Table no.9).Fever (70.6\%) followed by weight loss (53.3\%), chronic diarrhea (43.9\%) and cough (40.3\%) were the most common presenting symptoms in a study by Chakravarty $\mathrm{J}$ et $\mathrm{al}^{17}$.In a study by Carr et $\mathrm{al}^{10}, 3.3 \%$ reported previous history of fracture occurring over the age of 18 
years after no or minimal trauma. This variation in recruited subjects may be explained by the fact that in our study all subjects except one were on HAART and 80(62.9\%) subjects had CD4 count $>400$ at the time of presentation.

In our study, out of $127,71(55.90 \%)$ subjects were on TLE (Tenofovir, Lamivudine, Efavirenz) regimen followed by $49(38.58 \%)$ on ZLN (Zidovudine, Lamivudine, Nevirapine). 1 patient out of 127 was not on HAART(Highly active anti retroviral therapy)(Table no. 10).

In our study, CD4 count was done in all 127 subjects at the time of admission, majority i.e 44(34.64\%) had CD4 count between 251-500 (Table no. 11). 95 subjects had baseline CD4 count < 400 and 32 subjects had CD4 count > 400.

\section{Conclusion}

The present study found that most of the HIV infected patients were from sexually active age group. The commonest mode of acquiring infection was heterosexual contact, emphasizing the need to strengthen our Information education and communication (IEC) strategies to contain HIV/AIDS.

The majority of the seropositive population in this study was from lower socioeconomic class and between age group, i.e. 31 and 40 years. As this is the major part of reproductive age group, it significantly affects the development of the community.

HIV is a major global health problem. The global prevalence of people living with HIV has increased fourfold since 1990. People with high risk behavior and the spouse of the affected need to be educated for primary and secondary prevention of the disease. HIV patients should be educated that the timely initiation and continuous intake of antiretroviral therapy will not only prolong their survival but will also decrease the viral load and transmission of the disease.

Funding: No funding sources

Conflict of interest: None declared
Ethical Approval: The study was approved by the Institutional Ethics Committee

\section{Bibliography}

1. Global AIDS Update 2015: UNAIDS. www.unaids.org (Last accessed on 10-112017).

2. World Health Organization. Global health sector strategy on HIV,2016-2021. Available from: URL :http :// apps. Who .int/ mediacentre / factsheets/fs360/en/ (Last accessed on 10-11-2017).

3. Fauci Anthony S.,Lane H. Clifford. Harrison's Principles of Internal Medicine, $19^{\text {th }}$ ed McGraw-Hill, 2015: 1215-85.

4. India HIV Estimates 2015: Technical Report: National AIDS Control Organization. www.naco.gov.in. (Last accessed on 10-11-2017).

5. India HIV Estimates 2016: Annual Report: National AIDS Control Organization. www.naco.gov.in.annual report 2016-2017 (Last accessed on 10-11-2017).

6. World Health Organization: WHO case definitions of HIV for surveillance and revised clinical staging and immunological classification of HIV-related disease in adults and children 2007.

7. Umesh S Joge et al. Sociodemographic and clinical profile of HIV/AIDS patients visiting to ART centre at a rural tertiary care hospital in Maharashtra state of India: International Journal of Biological \&Medical Research 2012;3(2):1568-1572.

8. Gautam L, Deshpande JD, Somasundaram KV. Prevalence of HIV-TB co-infection, clinical profile and CD4 count of HIV patients attending ART centre of Ahmednagar, Maharashtra. International Journal of Medical Science and Public Health. 2014;3(9):1105-9.

9. Kamath R, Sharma V, Pattanshetty $\mathrm{S}$ et al. HIV-TB coinfection: Clinicoepidemiological determinants at an 
antiretroviral therapy center in Southern India. Lung India 2013;30(4):302-06.

10. A Carr et al, Prevalence of and risk factors for low bone mineral density in untreated HIV infection: a sub study of the INSIGHT Strategic Timing of Anti Retroviral Treatment (START) trial. DOI: 10.1111/hiv.12242 HIV Medicine (2015), 16 (Suppl. 1), 137-146.

11. Alonge TO, Okoje-Adesomoju VN, Atalabi OM , Obamuyide HA, Olaleye D, Adewole If. Prevalence of abnormal bone mineral density in hiv-positive patients in Ibadan, Nigeria. Journal of the west african college of surgeons volume 3 number 4, October - December 2013.

12. Sharma SK, Kohli M, Yadav RN et al. Evaluating the Diagnostic Accuracy of Xpert MTB/RIF Assay in Pulmonary Tuberculosis. PLoS ONE 2015;10 (10):e0141011.

13. Balasundaram A, Sarkar S, Hamide A, Lakshminarayanan S. Socioepidemiologic profile and treatment-seeking behaviour of HIV/AIDS patients in a tertiary-care hospital in South India. Journal of health, population, and nutrition. $2014 \mathrm{Dec} ; 32$ (4):587.

14. Khan MA. Socio-demographic and clinical profile of people living with HIV/Aids. Asian Journal of Medical Sciences (EISSN 2091-0576; P-ISSN2467-9100). 2014 Jul 2;3(2):1-0.

15. Rai P, Verma BL. A study on depression in people living with HIV/AIDS in SouthWest part of Uttar Pradesh, India .South East Asia Journal of Public Health. 2015 Sep13;5(1):12-7.

16. Ghiya R, Naik E, Casanas B et al.Clinicalepidemiological profile of HIV/TB coinfected patients in Vadodara, Gujarat. Indian journal of sexually transmitted diseases 2009;30:10-15.
17. J Chakravarty, H Mehta et al. Study on Clinico-epidemiological Profile of HIV Patients in Eastern India. JAPI: Vol 54: November 2006. 